\title{
Pengaruh Kepemimpinan Terhadap Efektivitas Kelompok P3A Ngudi Makmur dalam Pengelolaan Irigasi Usahatani Padi di Kecamatan Metro Selatan Kota Metro
}

\section{The Effects of Leadership on the Effectiveness of P3A Ngudi Makmur Group in the Management of Rice Farming Irrigation in South Metro Subdistrict Metro City}

\author{
Oleh: \\ Yazid Bertho Lansia ${ }^{*}$, Dame Trully Gultom ${ }^{2}$ dan Indah Nurmayasari ${ }^{2}$ \\ ${ }^{1}$ Jurusan Agribisnis, Fakultas Pertanian, Universitas Lampung \\ ${ }^{2}$ Program Studi Penyuluhan Pertanian, Fakultas Pertanian, Universitas Lampung \\ *e-mail: yazid.bertho@yahoo.co.id
}

Received: July 08, 2020; Revised: March 23, 2021; Accepted: June 08, 2021

\begin{abstract}
ABSTRAK
Penelitian ini bertujuan untuk mengetahui kepemimpinan ketua kelompok, efektifitas kelompok, dan pengaruh kepemimpinan ketua kelompok terhadap efektivitas kelompok Perkumpulan Petani Pemakai Air (P3A) Ngudi Makmur dalam pengelolaan irigasi usahatani padi. Penelitian ini dilakukan di Desa Margodadi, Kecamatan Metro Selatan, Kota Metro menggunakan metode survei. Sampel penelitian adalah 65 anggota kelompok P3A Ngudi Makmur yang dipilih secara acak. Penelitian ini menggunakan analisis deskriptif dan pemodelan persamaan struktural (SEM) metode partial least square (PLS). Hasil studi menunjukkan kepemimpinan ketua kelompok P3A tergolong kategori sedang dan Efektivitas kelompok P3A Ngudi Makmur tergolong kategori tinggi. Ada pengaruh nyata kepemimpinan ketua kelompok P3A terhadap efektivitas kelompok P3A Ngudi Makmur dalam pengelolaan irigasi.
\end{abstract}

Kata kunci: efektivitas, kelompok petani pemakai air (P3A), kepemimpinan.

\section{ABSTRACT}

This study aims to explore the leadership of water user group (P3A) leader, the level of group effectiveness, and the effects of the leadership on the effectiveness of the group in the management of rice farming irrigation. This research was conducted in Margodadi Village, South Metro Subdistrict, Metro City using a survey method. The research sample was 65 members of water user group (P3A) Ngudi Makmur selected using randomly. The research used descriptive analyis and structural equation modelling (SEM) with partial least square (PLS) method. The results showed that the leadership of water user group (P3A) leader is classified as medium category and the effectiveness of the water user group is classified as high category. The leadership of the group leader influences the effectiveness of P3A Ngudi Makmur in the irrigation management.

Keywords: effectiveness, leadership, water user group (P3A).

\section{PENDAHULUAN}

Pembangunan pertanian penting dalam pembangunan nasional yang bertujuan memperluas lapangan kerja, meningkatkan hasil mutu produk, pendapatan dan taraf hidup petani, serta meningkatkan ekspor (Todaro dan Smith, 2003). Keberhasilan pembangunan pertanian tidak bias terlepas dari partisipasi masyarakat tani (Nurmayasari et al, 2020). Menurut Balai Besar Penelitian Tanaman Padi Kementerian 
Pertanian pada tahun 2015 , komoditas padi berperan penting dalam meningkatkan pertumbuhan ekonomi Indonesia. Penduduk Indonesia di pedesaan diperkirakan lebih dari 60 persen terlibat dalam usahatani padi.

Menurut BPS (2018), jumlah produksi padi sawah di Indonesia pada tahun 2015 2017 terjadi peningkatan 5.599 .553 ton atau sebesar 7,8\%. Hal ini berarti padi yang merupakan komoditas pangan pokok masyarakat Indonesia terus meningkat setiap tahunnya. Sektor pertanian merupakan salah satu pilar utama pertumbuhan ekonomi daerah Lampung (Gultom, 2017). Menurut BPS (2018), Provinsi Lampung memiliki luas lahan sawah dengan jenis pengairan menggunakan irigasi seluas 191.925 hektar. Proses bercocok tanam padi sawah membutuhkan saluran irigasi untuk mengairi lahan sawah.

Menurut Dinas Penanaman Modal dan Pelayanan Terpadu Satu Pintu Provinsi Lampung tahun 2017, total saluran irigasi di Provinsi Lampung mencapai $371.417 \mathrm{~km}$. Provinsi Lampung juga memiliki sumberdaya air daerah river basin (sungai besar) yang dimanfaatkan sebagai daerah pengembangan sawah irigasi teknis seluas hampir 295.544 ha (areal potensial 285.376 hektar, areal baku 264.768 hektar, dan areal fungsional 190.959 hektar). Besarnya potensi air di Provinsi Lampung untuk mengembangkan pengairan terutama pada sawah irigasi, sangat diperlukan pengelolaan yang baik seperti pembangunan dan pengelolaan irigasi untuk mewujudkan kedaulatan pangan khususnya padi.

Menurut Mardikanto (1993), salah satu faktor yang dapat memperlancar pembangunan pertanian adalah adanya kesadaran individu. Adanya kesadaran individu tersebut petani bergabung kedalam suatu wadah yaitu kelompok. Irigasi dikelola oleh Perkumpulan Petani Pemakai Air (P3A) yang merupakan kelembagaan pengelolaan irigasi yang menjadi suatu wadah untuk petani pemakai air dalam suatu daerah pelayanan irigasi yang dibentuk oleh petani pemakai air sendiri secara demokratis, termasuk kelembagaan lokal pengelola air irigasi (Departemen Pertanian, 2008).

Provinsi Lampung terutama di Kota Metro memiliki luas lahan sawah sejumlah 2.984 ha dimana 2.926 ha adalah lahan sawah dengan jenis pengairan irigasi (BPS, 2018). Irigasi yang dikelola oleh P3A, terdapat juga di Kota Metro. Kota Metro memiliki total 11 kelompok P3A. P3A Ngudi Makmur, Kelurahan Margodadi memiliki total saluran irigasi sepanjang 16.873 meter (6.422 meter tersier, 10.451 meter kwarter) dan memiliki anggota sebanyak 413 anggota. Hal tersebut berarti bahwa P3A Ngudi Makmur menjadi P3A dengan jumlah saluran irigasi terpanjang dan jumlah anggota terbanyak pada urutan pertama dari keseluruhan Petani Pemakai Air (P3A) di Kota Metro.

Terdapat lima peran kepemimpinan yang di nilai yakni mengidentifikasi dan menganalisis organisasi serta tujuannya (Yunasaf, 2004). Berdasarkan latar belakang P3A Ngudi Makmur dengan jumlah saluran terpanjang dan anggota terbanyak di Kota Metro tersebut, maka peneliti melakukan penelitian tentang Pengaruh Kepemimpinan Ketua Kelompok P3A terhadap Efektivitas Kelompok P3A Ngudi Makmur dalam Pengelolaan Irigasi Usahatani Padi Sawah di Kecamatan Metro Selatan, Kota Metro.

\section{METODE PENELITIAN}

Penelitian ini dilakukan di Kelurahan Margodadi, Kecamatan Metro Selatan, Kota Metro. Penentuan lokasi dilakukan secara sengaja dengan pertimbangan bahwa Kota Metro merupakan sentra komoditas pangan di Provinsi Lampung dengan jenis pengairan menggunakan irigasi pada usahatani padi sawah. Pemilihan kelompok dengan pertimbangan bahwa P3A Ngudi Makmur adalah P3A dengan total saluran irigasi terpanjang dan anggota terbanyak dari keseluruhan P3A di Kota Metro. Waktu penelitian dilakukan bulan Juli - September 2019. Jumlah populasi anggota P3A sebanyak 413 orang. Teknik pengambilan sampel menggunakan sample random sampling. 
Penentuan lokasi penelitian diperoleh dengan pertimbangan Kelurahan Margodadi salah satu kelurahan yang menjalankan program P3A dan P3A Ngudi Makmur menjadi $\mathrm{P} 3 \mathrm{~A}$ dengan total saluran irigasi terpanjang dan jumlah anggota terbanyak. Penentuan jumlah sampel menggunakan rumus Sugiarto, dkk (2003) dengan perhitungan sebagai berikut:

$$
\begin{gathered}
\mathrm{n}=\frac{\mathrm{N} \mathrm{Z} \mathrm{Z}^{2}}{\mathrm{Nd}^{2}+\mathrm{Z}^{2} \mathrm{~S}^{2}} \\
\mathrm{n}=\frac{(413)(1,96)^{2}(0,05)}{413(0,05)^{2}+(1,96)^{2}(0,05)}=65 \text { orang }
\end{gathered}
$$

Keterangan :

$\mathrm{n} \quad=$ Jumlah sampel (orang)

$\mathrm{N} \quad=$ Jumlah populasi (413 orang)

$\mathrm{Z} \quad=$ Tingkat kepercayaan $(1,96)$

$\mathrm{S}^{2} \quad=$ Variasi sampel $(0,05)$

$\mathrm{d}=$ Derajat penyimpangan $(0,05)$

Metode penentuan jumlah sampel juga digunakan oleh Aldila, Nikmatullah, dan Hasanuddin (2018). Metode dalam penelitian ini adalah metode survei yakni penelitian yang mengambil sampel untuk mewakili populasi dengan menggunakan kuesioner sebagai pengumpul data. Data dalam penelitian ini adalah data primer dan data sekunder. Data primer didapat melalui wawancara dengan responden. Sedangkan data sekunder didapat dari studi literatur terhadap instansi atau dinas terkait serta lembaga yang berhubungan dengan penelitian ini.

Pengolahan data dilakukan dengan metode analisis deskriptif untuk mengetahui tingkat kepemimpinan ketua kelompok P3A dengan efektivitas kelompok P3A Ngudi Makmur yang diukur menggunakan rumus modus. Menurut Sugiyono (2010), rumus modus adalah sebagai berikut:

$$
M_{0}=b+p\left(\frac{b_{1}}{b_{1}+b_{2}}\right)
$$

Metode analisis deskriptif pendekatan kualitatif bertujuan mendapatkan gambaran secara faktual, sistematis dan akurat mengenai sifat, fakta serta hubungan mengenai indikator dalam variabel yang ada pada penelitian.

Pengujian hipotesis dan analisis data dalam penelitian ini menggunakan SEM (Structural Equation Modelling) metode PLS (Partial Least Square). Metode PLS juga digunakan oleh Fitriana, Abidin, dan Endaryanto (2017). Analisis Structural Equation Modelling (SEM) juga digunakan oleh Gultom (2017). SEM (Structural Equation Modelling) metode PLS (Partial Least Square) bertujuan menghitung pengaruh yang ada dari hubungan antar variabel laten yang diolah berdasarkan hasil dari pengumpulan data melalui responden dengan cara sebagai berikut:

1. Merancang Model Pengukuran (Outer Model)

Tahap awal yaitu Outer Model, membuat model yang menspesifikasikan hubungan antara variabel dengan indikatornya.

2. Merancang Model Struktural (Outer Model)

Tahap selanjutnya yaitu Inner model, membuat spesifikasi hubungan antar satu variabel dengan laten lainnya.

3. Estimasi Koef Jalur dan Loading Faktor Tahapan selanjutnya yaitu menghitung koefisen jalur untuk melihat hubungan antar variabel laten dan loading faktor untuk melihat hubungan antar variabel laten dengan indikatornya.

4. Evaluasi Goodness of Fit

Evaluasi dilakukan dengan menggunakan tiga kriteria. Strandarisasi dan kriteria evaluasi outer model adalah sebagai berikut

a. Convergent Validity (Reliabilitas Indikator)

Kriteria dilihat dari nilai loading faktor masing-masing indikator harus $>0,7$. Apabila nilainya kurang dari itu maka harus dibuang dan dilakukan analisis ulang dengan Software SmartPLS. 
b. Discriminant Validity

Nilai discriminant validity dilihat berdasarkan crossloading pengukuran dengan variabel. Metodenya adalah membandingkan nilai square root of average variance extracted (AVE) setiap variabel. Apabila nilai $A V E$ setiap variabel lebih besar dibanding nilai korelasi antara variabel dengan variabel lainnya dalam model, maka dikatakan memiliki nilai discriminant validity yang baik. Nilai $A V E$ direkomendasikan $>0,5$.

c. Composite Reliability

Nilai composite reliability menunjukkan nilai reliabilitas dari indikator. Penelitian suatu variabel dikatakan cukup reliabilitas jika variabel tersebut memiliki nilai composite reliability $>0,7$. Apabila nilai tersebut $<0,7$ maka indikator tersebut tidak dapat digunakan dalam penelitian.

5. Evaluasi Inner Model (Model Struktural) Analisis ini melakukan dua tipe uji yakni nilai $R^{2}$ untuk setiap variabel laten menggunakan path coefficient estimation dan PLS Algoritm dengan menggunakan cara bootstraping. Nilai $R^{2}$ bertujuan guna menjelaskan pengaruh dari variabel laten eksogen yang diberikan terhadap variabel laten endogen. Hal tersebut untuk melihat adanya pengaruh substantif atau tidak. Uji selanjutnya adalah pengujian hipotesis melalui metode resampling bootstrapping dengan menghasilkan gambar bootstrap untuk mengetahui nilai T-statistik dan Path coefficient yang digunakan untuk melihat nilai asli sampel (Ghozali, 2008).

Kaidah pengambilan keputusan adalah :

1. Jika t hitung $\leq \mathrm{t}$ tabel, maka tolak $\mathrm{H} 1$ pada $(\alpha)=0,05$ atau $(\alpha)=0,01$. Artinya tidak terdapat pengaruh yang nyata antara kedua variabel yang diuji.

2. Jika $\mathrm{t}$ hitung $>\mathrm{t}$ tabel, maka terima $\mathrm{H} 1$ pada $(\alpha)=0,05$ atau $(\alpha)=0,01$. Artinya terdapat pengaruh yang nyata antara kedua variabel yang diuji.
Pengujian antar indikator valid digunakan untuk melihat pengaruh indikator variabel Kepemimpinan Ketua Kelompok P3A terhadap Efektivitas Kelompok P3A dengan menggunakan Analisis Regresi Sederhana dengan metode tabulasi, komputerisasi (Microsoft Excel). Metode analisis ini sejalan dengan penelitian Putri, Lestari, dan Rangga (2016). Menurut Ghozali (2006) analisis ini bertujuan untuk mengetahui seberapa besar pengaruh variabel independen terhadap variabel dependen. Regresi digunakan untuk mengukur besarnya pengaruh variabel bebas terhadap variabel terikat dan memprediksi variabel terikat dengan menggunakan variabel bebas.

Kaidah pengambilan keputusan adalah :

1. Jika nilai signifikasi $\leq$ probabilitas 0,05 . Artinya terdapat pengaruh yang nyata antara kedua indikator yang diuji.

2. Jika nilai signifikasi > probabilitas 0,05 . Artinya tidak terdapat pengaruh yang nyata antara kedua indikator yang diuji.

\section{HASIL DAN PEMBAHASAN}

\section{Keadaan Umum Responden}

Jumlah responden dalam penelitian adalah 65 orang petani di Kelurahan Margodadi, Kecamatan Metro Selatan, Kota Metro. Responden penelitian ini adalah petani anggota P3A Ngudi Makmur. Klasifikasi Angkatan Kerja Nasional menurut BPS (2003) yaitu usia belum produktif ( $<15$ tahun), usia produktif $(>15-64$ tahun ) dan usia tidak produktif ( $>64$ tahun). Hasil penelitian menunjukkan responden memiliki rata-rata usia 52,85 tahun atau berusia produktif. Pendidikan formal yang ditempuh oleh responden adalah rata-rata 8,34 tahun atau pada klasifikasi pendidikan rendah. Lama waktu menjadi anggota P3A responden adalah rata-rata 20,02 tahun atau pada klasifikasi anggota lama. Luas lahan responden petani anggota $\mathrm{P} 3 \mathrm{~A}$ memiliki ratarata luas lahan 0,60 hektar atau berada pada klasifikasi lahan sempit. Produksi padi dalam satu musim tanam pada tahun 2019 
memiliki nilai rata-rata 2,4 ton atau berada pada klasifikasi produksi rendah. Produktivitas padi responden petani anggota P3A Ngudi Makmur memiliki nilai rata-rata 4,33 ton/ha atau berada pada klasifikasi tinggi.

\section{Variabel Kepemimpinan Ketua Kelompok P3A (X)}

Kepemimpinan ketua kelompok P3A sangat menentukan sikap anggota terhadap perintah/informasi yang diberikan. Kesesuaian keadaan dan kondisi kelompok dengan kepemimpinan ketua kelompok akan mewujudkan keefektifan kelompok yang dibina. Indikator pengukuran kepemimpinan adalah sifat pemimpin, kekuasaan pemimpin, pemberian motivasi, pengambilan keputusan dan cara berkomunikasi. Pengklasifikasian indikator kepemimpinan dimasukkan kedalam tiga kelas yaitu skor tiga (tinggi), skor dua (sedang) dan skor satu (rendah) dengan menggunakan rumus modus (Sugiyono, 2010).

Tabel 1.

Rekapitulasi kepemimpinan ketua kelompok P3A

\begin{tabular}{lcccc}
\hline $\begin{array}{c}\text { Kepemimpinan } \\
\text { ketua }\end{array}$ & $\begin{array}{c}\text { Tinggi } \\
\text { (skor }\end{array}$ & $\begin{array}{c}\text { Sedang } \\
\text { (skor }\end{array}$ & $\begin{array}{c}\text { Rendah } \\
\text { (skor }\end{array}$ & $\sum$ \\
kelompok P3A & 3 ) & 2 ) & 1 ) & \\
\hline Responden & 27 & 38 & 0 & 65 \\
Persentase & 41,5 & 58,5 & 0 & 100 \\
\hline
\end{tabular}

Pada Tabel 1 hasil rekapitulasi mayoritas responden sebanyak 38 petani anggota P3A menunjukkan kepemimpinan ketua kelompok P3A berada pada klasifikasi sedang. Hal ini berarti bahwa kepemimpinan ketua kelompok P3A Ngudi Makmur memberikan dampak yang positif terhadap jalannya organisasi. Ketua kelompok dapat diterima dan disegani anggota P3A dengan kinerja yang telah ditunjukkan. Kemampuan ketua kelompok dalam mengarahkan pencapaian tujuan kelompok, pengambilan keputusan saat rapat kelompok serta dalam meyampaikan poin pembicaraan dapat dimengerti oleh anggota kelompok P3A Ngudi Makmur.

\section{Variabel Efektivitas Kelompok P3A (Y)}

Keefektifan kelompok berpengaruh dengan tercapainya tujuan kelompok yang disertai dengan kepuasan anggota sebagai anggota P3A. Indikator efektivitas adalah produktivitas kelompok, moral kelompok dan kepuasan anggota. Keefektifan kelompok diklasifkan kedalam tiga kelas yaitu skor tiga (tinggi), skor dua (sedang) dan skor satu (rendah) dengan menggunakan rumus modus (Sugiyono, 2010).

Hasil penelitian mayoritas responden sebanyak 45 petani anggota P3A masuk dalam klasifikasi tinggi. Hal ini menunjukkan bahwa kepemimpinan ketua kelompok memberikan manfaat dari pelaksanaan dan pengelolaan jaringan irigasi serta berdampak positif kepada petani anggota P3A Ngudi Makmur yaitu terkoordinirnya pembangunan fisik irigasi baru sepanjang 527 meter, renovasi saluran irigasi lama sepanjang 300 meter dan bantuan bibit $20 \mathrm{~kg} / \mathrm{ha} /$ petani.

Kepuasan anggota kelompok atas dihapusnya iuran pipa air sebesar Rp. 8.000,00/anggota sehingga meminimalisir pengeluaran anggota kelompok P3A. Rutinnya pertemuan antar anggota kelompok P3A sehingga mempermudah petani anggota P3A dalam menyampaikan aspirasi atau keluhan. Rekapitulasi efektivitas kelompok P3A dapat dilihat pada Tabel 2.

Tabel 2.

Rekapitulasi efektivitas kelompok P3A

\begin{tabular}{lcccc}
\hline $\begin{array}{c}\text { Efektivitas } \\
\text { kelompok } \\
\text { P3A }\end{array}$ & $\begin{array}{c}\text { Tinggi } \\
\text { (skor 3) }\end{array}$ & $\begin{array}{c}\text { Sedang } \\
\text { (skor } \\
\text { 2) }\end{array}$ & $\begin{array}{c}\text { Rendah } \\
\text { (skor } \\
1)\end{array}$ & $\Sigma$ \\
\hline Responden & 45 & 20 & 0 & 65 \\
Persentase & 69,2 & 30,8 & 0 & 100 \\
\hline
\end{tabular}

\section{Analisis Pengaruh Variabel Kepemimpinan Ketua Kelompok dan Variabel Efektivitas Kelompok P3A}

Pengaruh antara variabel kepemimpinan ketua kelompok terhadap variabel efektivitas kelompok P3A dianalisis dengan menggunakan statistik parametrik uji 
Structural Equation Modelling (SEM) metode Partial Least Square (PLS). Hasil nilai path coeficient parameter, running bootstrapping dan pengujian hipotesis kepemimpinan ketua kelompok P3A dengan efektivitas kelompok P3A Ngudi Makmur dapat ditunjukkan pada tabel 3 .

Tabel 3.

Hasil nilai path coeficient parameter, running bootstrapping dan pengujian hipotesis kepemimpinan ketua kelompok dengan efektivitas kelompok

\begin{tabular}{lcccc}
\hline Path coefficient & $\begin{array}{c}\text { Org } \\
\text { sample }\end{array}$ & $\begin{array}{c}\text { Std } \\
\text { error }\end{array}$ & $\begin{array}{c}\text { T sta- } \\
\text { tistics }\end{array}$ & Hasil \\
\hline $\begin{array}{l}\text { Kepemimpinan } \\
\text { ketua kelompok }\end{array}$ & & & & \\
$\begin{array}{l}\text { P3A dengan } \\
\text { efektivitas }\end{array}$ & 0,4292 & 0,1123 & 3,8208 & Signifikan \\
kelompok P3A & & & & \\
Ngudi Makmur & & & & \\
\hline
\end{tabular}

Hasil nilai outer loading indikator menunjukkan indikator sifat pemimpin dan pengambilan keputusan adalah indikator valid dari variabel $X$, sedangkan indikator valid dari variabel $\mathrm{Y}$ adalah indikator produktivitas kelompok dan moral kelompok. Hasil uji reliabilitas variabel $\mathrm{X}$ dan Y menunjukkan variabel kepemimpinan ketua kelompok memiliki nilai AVE $(0,6175)$ dan nilai $\rho \_c(0,7589)$ sedangkan variabel efektivitas kelompok P3A memiliki nilai $\operatorname{AVE}(0,8292)$ dan nilai $\rho_{-} c(0,9066)$ maka dapat disimpulkan variabel yang digunakan mempunyai nilai discriminant validity dan reliabilitas yang cukup baik. Hasil Uji T pada output PLS menunjukkan nilai t-hitung $(3,8208)>$ T-tabel $(1,96)$ atau thitung lebih besar dari T-tabel maka dapat disimpulkan bahwa kepemimpinan ketua kelompok P3A mampu mempengaruhi tingkat efektivitas kelompok P3A Ngudi Makmur secara positif.

Hasil penelitian ini menunjukkan bahwa kepemimpinan ketua kelompok memberikan dampak positif seperti menurunnya biaya produksi petani karena terkoordinirnya bantuan yang ada oleh pengurus, peningkatan produktivitas karena telah disosialisasikan cara penanganan hama yang dapat merusak hasil produksi petani, pembagian air serta pembersihan jaringan irigasi secara terjadwal, kepuasan anggota terhadap terkoordinirnya pembangunan baru dan renovasi jaringan irigasi serta penghapusan iuran sesuai aspirasi petani anggota P3A Ngudi Makmur. Hasil penelitian sejalan dengan penelitian yang dilakukan oleh Anggunanda, Hasanuddin, dan Nurmayasari (2016), yang menyatakan bahwa terdapat hubungan yang nyata atau signifikan antara kepemimpinan ketua kelompok dengan keefektifan kelompok tani.

\section{Analisis Indikator}

Tabel 4.

Hasil uji signifikansi pada indikator

\begin{tabular}{|c|c|c|}
\hline Laten & Indikator & $\begin{array}{c}\text { Outer } \\
\text { Loading }\end{array}$ \\
\hline Kepempinan & Sifat Pemimpin & 0,900660 \\
\hline Ketua & Pengambilan & \\
\hline Kelompok & Keputusan & 0,651063 \\
\hline Efektivitas & Produktivitas & 0885457 \\
\hline Kelompok & Kelompok & ו \\
\hline P3A & Moral Kelompok & 0,935113 \\
\hline
\end{tabular}

Hasil outer loading pada software SmartPLS terdapat indikator yang memiliki nilai outer loading $<0,6$ yaitu indikator kekuasaan pemimpin, pemberian motivasi, cara berkomunikasi dan kepuasan anggota. Hal ini menunjukkan bahwa indikator tersebut kurang baik dalam menjelaskan variabelnya, maka indikator tersebut tidak dimasukkan kedalam model. Indikator yang valid dan memiliki nilai outer loading $>0,6$ yaitu indikator sifat pemimpin, pengambilan keputusan, produktivitas kelompok dan moral kelompok.

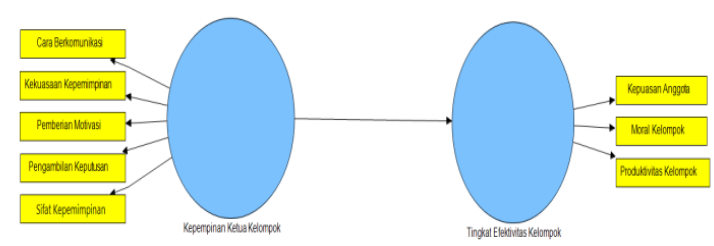

Gambar 1.

Model awal (outer model) indikator kepemimpinan ketua kelompok terhadap efektivitas kelompok P3A 


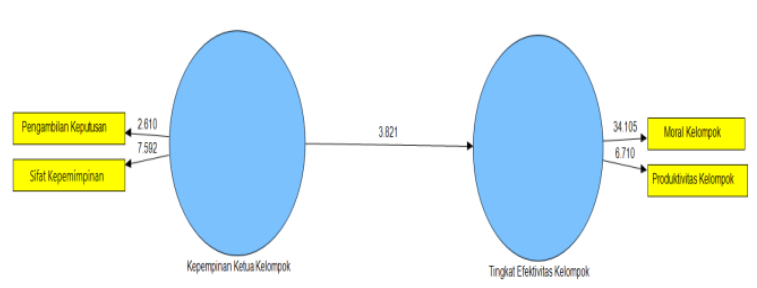

Gambar 2.

Inner model indikator kepemimpinan ketua kelompok terhadap efektivitas kelompok P3A

Pengujian antar indikator valid digunakan untuk melihat indikator paling berpengaruh diantara variabel kepemimpinan ketua kelompok dengan efektivitas kelompok P3A menggunakan analisis regresi sederhana dengan aplikasi Eviews 9 dengan hasil sebagai berikut:

a. Analisis indikator sifat pemimpin terhadap produktivitas kelompok

Hasil analisis indikator sifat pemimpin terhadap produktivitas kelompok memiliki nilai $\mathrm{R}$-squared sebesar 0,179 atau $17,9 \%$, artinya sebesar $17,9 \%$ variasi produktivitas kelompok diterangkan oleh sifat pemimpin, sedangkan sisanya $82,1 \%$ dijelaskan oleh indikator lain yang tidak dimasukkan dalam model. Nilai Fhitung produktivitas kelompok sebesar 13,77510 dengan probabilitas 0,0004 yang artinya indikator sifat pemimpin berpengaruh nyata terhadap variasi produktivitas kelompok dengan tingkat kepercayaan 99\%. Nilai t-hitung sifat pemimpin sebesar 3,711 dengan nilai Sig 0,000 artinya indikator sifat pemimpin berpengaruh nyata terhadap produktivitas kelompok dengan tingkat kepercayaan sebesar $99 \%$.

b. Analisis indikator sifat pemimpin terhadap moral kelompok

Hasil analisis indikator sifat pemimpin terhadap moral kelompok memiliki nilai R-squared sebesar 0,030 atau 3\%, artinya sebesar 3\% variasi moral kelompok diterangkan oleh sifat pemimpin, sedangkan sisanya $97 \%$ dijelaskan oleh indikator lain yang tidak dimasukkan dalam model. Nilai F-hitung produktivitas kelompok sebesar 1,96509 dengan probabilitas 0,1658 yang artinya indikator sifat pemimpin tidak berpengaruh nyata terhadap variasi moral kelompok karena tingkat kepercayaannya hanya $83,42 \%$. Nilai t-hitung sifat pemimpin sebesar 1,401 dengan nilai Sig 0,1659 artinya indikator sifat pemimpin tidak berpengaruh nyata terhadap moral kelompok karena tingkat kepercayaannya hanya sebesar $83,4 \%$.

c. Analisis indikator pengambilan keputusan terhadap produktivitas kelompok

Hasil analisis indikator sifat pemimpin terhadap produktivitas kelompok memiliki nilai R-squared sebesar 0,019 atau $1,9 \%$, artinya sebesar $1,9 \%$ variasi produktivitas kelompok diterangkan oleh pengambilan keputusan, sedangkan sisanya $98,1 \%$ dijelaskan oleh indikator lain yang tidak dimasukkan dalam model. Nilai F-hitung produktivitas kelompok sebesar 1,27767 dengan probabilitas 0,2626 yang artinya indikator pengambilan keputusan tidak berpengaruh nyata terhadap variasi produktivitas kelompok karena tingkat kepercayaannya hanya $73,74 \%$. Nilai thitung sifat pemimpin sebesar 1,1303 dengan nilai Sig 0,2626 artinya indikator pengambilan keputusan tidak berpengaruh nyata terhadap produktivitas kelompok karena tingkat kepercayaannya hanya sebesar $73,74 \%$.

d. Analisis indikator pengambilan keputusan terhadap moral kelompok Hasil analisis indikator pengambilan keputusan terhadap moral kelompok memiliki nilai R-squared sebesar 0,025 atau $2,5 \%$, artinya sebesar $2,5 \%$ variasi moral kelompok diterangkan oleh pengambilan keputusan, sedangkan sisanya $97,5 \%$ dijelaskan oleh indikator lain yang tidak dimasukkan dalam model. Nilai F-hitung produktivitas kelompok sebesar 1,68120 dengan probabilitas 
0,1994 yang artinya indikator pengambilan keputusan tidak berpengaruh nyata terhadap variasi moral kelompok karena tingkat kepercayaannya hanya $80,06 \%$. Nilai t-hitung sifat pemimpin sebesar 1,2966 dengan nilai Sig 0,1995 artinya indikator pengambilan keputusan tidak berpengaruh nyata terhadap produktivitas kelompok karena tingkat kepercayaannya hanya sebesar $80,05 \%$.

Dari ke-empat indikator di uji, disimpulkan bahwa indikator yang paling berpengaruh adalah indikator sifat pemimpin terhadap produktivitas kelompok dengan nilai F-hitung produktivitas kelompok sebesar 13,7751 dengan probabilitas 0,0004 yang artinya indikator sifat pemimpin berpengaruh nyata terhadap variasi produktivitas kelompok dengan tingkat kepercayaan $99 \%$. Nilai t-hitung sifat pemimpin sebesar 3,711 dengan nilai Sig 0,000 artinya indikator sifat pemimpin berpengaruh nyata terhadap produktivitas kelompok dengan tingkat kepercayaan sebesar $99 \%$.

\section{SIMPULAN}

Kepemimpinan ketua kelompok P3A terhadap pengelolaan irigasi usahatani padi sawah di Kelurahan Margodadi Kecamatan Metro Selatan masuk dalam kategori sedang $(84,62 \%)$ bahwa kepemimpinan ketua kelompok cukup memberikan dampak positif terhadap jalannya organisasi. Efektivitas kelompok P3A terhadap pengelolaan irigasi usahatani padi sawah masuk dalam kategori tinggi $(61,54 \%)$ bahwa efektivitas kelompok P3A sangat baik yang dipengaruhi oleh kepemimpinan ketua kelompoknya. Kepemimpinan ketua kelompok (X) berpengaruh nyata dengan efektivitas kelompok P3A (Y) atau kepemimpinan ketua kelompok (X) mampu mempengaruhi tingkat efektivitas kelompok P3A (Y) secara positif di P3A Ngudi Makmur pada pengelolaan irigasi usahatani padi sawah di Kelurahan Margodadi Kecamatan Metro Selatan.

\section{DAFTAR PUSTAKA}

Aldila B., Nikmatullah D., dan Hasanuddin T. 2018. Faktor-faktor yang berhubungan dengan Peranan Pengurus Badan Usaha Milik Pekon di Pekon Gisting Bawah. JIIA. Vol.6 No.2, Mei 2018. Hal 214-221. http://jurnal.fp.unila.ac.id/Index.php/JI A/article/view/2788 Diakses pada 29 mei 2020.

Anggunanda FT, Hasanuddin T, dan Nurmayasari I. 2016. Efektivitas Kepemimpinan Ketua Kelompok Tani dalam Difusi Inovasi Pengelolaan Tanaman Terpadu Padi di Kabupaten Lampung Selatan. JIIA. Vol.4 No.4, Oktober 2016. Hal 423-429. http://jurnal.fp.unila.ac.id/Index.php/JI

A/article/view/1525 Diakses pada 1 juni 2020.

Badan Pusat Statistik. 2018. Produksi, Luas Panen dan Produktivitas padi di Indonesia 2015 - 2017. Jakarta.

Badan Pusat Statistik. 2018. Provinsi Lampung Dalam Angka 2018. Lampung.

Balai Besar Penelitian Tanaman Padi Kementerian Pertanian. 2015. Ekonomi Beras Indonesia dan Peranan Beras dalam Pembangunan. Jakarta.

Dinas Penanaman Modal dan Pelayanan Terpadu Satu Pintu Provinsi Lampung. 2017. Sumber Daya Alam Provinsi Lampung. Lampung.

Fitriana V, Abidin Z, dan Endaryanto $\mathrm{T}$. 2017. Estimasi Permintaan dan Nilai Ekonomi Taman Wisata Alam Angke Kapuk Jakarta Utara. JIIA. Vol.5 No.3, Agustus 2017. Hal 267-274. http://jurnal.fp.unila.ac.id/Index.php/JI A/article/view/1639 Diakses pada 1 juni 2020.

Ghozali I. 2006. Aplikasi Analisis Multivariate dengan Program SPSS (Edisi Ke 4). Badan Penerbit UNDIP. Semarang.

Ghozali I. 2008. Structural Equation Modelling Edisi II. Badan Penerbit UNDIP. Semarang. 
Gultom DT. 2017. Strategi Pemenuhan Kebutuhan Informasi Pertanian Melalui Pemanfaatan Cyber Extension Di Provinsi Lampung. Jurnal Ilmu-ilmu Sosial dan Humaniora. Vol. 19 No.1 Maret 2017: 64-69. Direktorat Sumberdaya Akademik dan Perpustakaan Universitas Padjadjaran. http://jurnal.unpad.ac.id/sosiohumanior a/article/view/9289/6394. Diakses pada 14 Agustus 2020.

Mardikanto T. 1993. Penyuluhan Pembangunan Pertanian. Sebelas Maret University Press. Surakarta.

Nurmayasari I, Viantiamala B, Gultom DT, Yanfika H dan Muthalib A. 2020. Partisipasi Dan Kepuasan Petani Terhadap Kinerja Penyuluh Pertanian Di Kecamatan Palas Kabupaten Lampung Selatan. Jurnal Pemikiran Masyarakat Ilmiah Berwawasan Agribisnis. Vol.6 No.1, 448-459.

Putri AP, Lestari DAH, dan Rangga KK. 2016. Pengaruh Status Keanggotaan Koperasi Ism Mitra Karya Bahari terhadap Pendapatan Rumah Tangga Nelayan di Pulau Pasaran Bandar Lampung. JIIA. Vol.4 No.2, Mei 2016. Hal 178-185. http://jurnal.fp.unila.ac.id/Index.php/JI A/article/view/1235 Diakses pada 29 juni 2020.

Sugiarto, Siagian D, Sunaryanto LT, dan Oetomo DS. 2003. Teknik Sampling. PT. Gramedia Pustaka Utama. Jakarta.

Sugiono. 2010. Statistika Untuk Penelitian. Alfabeta. Bandung.

Todaro dan Smith. 2003. Pembangunan Ekonomi di Dunia Ketiga. Erlangga. Jakarta.

Yunasaf U. 2004. Kepemimpinan Pengurus Koperasi dalam Mendinamiskan Organisasi Koperasi (Kasus pada Koperasi Serba Usaha (KSU) Tandangsari, Sumedang). Sosiohumaniora $\quad 6(3), \quad 232$. http://jurnal.unpad.ac.id/sosiohumanior a/article/view/5531. Diakses pada 1 September 2020. 